\title{
AIRBORNE POLLEN: A UNIQUE AIR MASS TRACER, ITS INFLUX TO THE CANADIAN HIGH ARCTIC
}

\author{
by
}

\author{
J.C. Bourgeois, R.M. Koerner and B.T. Alt
}

(Polar Continental Shelf Project, Energy, Mines and Resources, 880 Wellington St., Ottawa, Ontario KIA 0E4, Canada)

\section{ABSTRACT}

A study of pollen grain concentration in surface snow and ice cores at 15 sites in the Canadian high Arctic and one site near the tree line, together with published pollen deposition rates south of the tree line has shown long-range dispersal of pollen from the boreal forest to the limits of our area on the Arctic Ocean close to Svalbard and the North Pole. There are no discernible trends of deposition rates within the high Arctic which suggests extremely long trajectories with strong zonal components; some of the pollen may have an Eurasian source. We relate the trajectories to synoptic patterns in the mid-and high Arctic.

\section{INTRODUCTION}

Pollen grains vary in size between approximately 10 and $150 \mu \mathrm{m}$. Wind-pollinated plants can produce millions of pollen grains each year. However, most of the pollen grains injected into the air will fall close to their source and only a few, termed the "escape fraction" (Gregory 1978), will be carried long distances. It is the "escape fraction", of about 10\% (Gregory 1978), with which this paper is concerned.

Throughout the text we use the term "exotic" to denote pollen types that originate outside the high Arctic (in this case the Queen Elizabeth Islands and the Arctic Ocean to their north); this includes ali arboreal pollen types except Salix. With respect to sites on the ice caps, none of the pollen grains or spores can be local so we use the term "regional" to refer to any pollen types that may originate within the high Arctic.

\section{PREVIOUS WORK}

Palynological work in the high Arctic has been almost entirely restricted to ice-free areas. Apart from work based on analyses of our cores and surface snow samples, the only glacier-based work of which we are aware is that of Fredskild and Wagner (1974) on cores from Camp Century and Dye 3 in Greenland (Fig.1: sites B and C), Kalugina and others (1979) from filtered air samples over Vavilov ice cap (Fig.1: site A) and Short and Holdsworth (personal communication) from shallow cores on Penny Ice Cap (Fig.1: site F). Fredskild and Wagner studied very small samples $(<1 \quad 1)$ which produced very few pollen grains. The statistical validity of their work is questionable. The work of Kalugina and others suffers from the same problems. However, both groups found pollen that must have originated south of the tree line in their samples.

Snow samples collected from Devon Island ice cap (Fig.1: site D) by the Polar Continental Shelf Project (PCSP) in 1973 were studied by Lichti-Federovich (1974), who found that there were seasonal differences in the rates of pollen deposition such that exotic arboreal pollen predominated in the winter and pollen of tundra origin predominated in snow deposited in the fall. Summer snow layers showed a scarcity of pollen. Lichti-Federovich (1975[b]) then studied a suite of surface snow samples collected by the PCSP from several ice caps. These samples also contained pollen exotic to the high Arctic, but the total numbers were too small to allow a proper statistical analysis.
While Lichti-Federovich (1975[a]) made an important pilot study of some ice cores from the Devon Island ice cap, McAndrews (1984) has made the most thorough palynological study to date of a continuous surface-to-bedrock core. His work, which analyses significant changes in the pollen concentration of the core with depth, shows the relevance of palynology to ice-core studies.

Our knowledge of the present-day deposition of pollen into the Arctic generally is largely due to the work of Ritchie and Lichti-Federovich (1967), although only one of their stations was in the high Arctic. They set out open Petri dish samplers at 29 sites across Canada between Moosonee (lat $51^{\circ} 17^{\prime} \mathrm{N}$, long $80^{\circ} 24^{\prime} \mathrm{W}$ ), south of the tree line, and Resolute Bay (Fig.1: site E) at the southern edge of the high Arctic. In addition, they collected pollen grains and spores in a Hirst automatic volumetric spore trap at Churchill (lat $57^{\circ} 46^{\prime} \mathrm{N}$, long $94^{\circ} 10^{\prime} \mathrm{W}$ ). They found that about $50 \%$ of the pollen types in the high and mid-Arctic were exotic arboreal types. Therefore, the spectra there do not accurately represent the nature of the regional vegetation.

More recently, Elliott-Fisk and others (1982) conducted a study of pollen rain in the eastern and mid-Arctic, using moss polsters and lichens as the pollen collector. They constructed isopoll and pollen concentration maps for the 39 sites but did not calculate pollen deposition rates.

\section{METHODS}

1. Field method

Because earlier work by Lichti-Federovich (1974) on Devon Island ice cap had indicated rates of pollen deposition as low as 7 grains $\mathrm{m}^{-2} \mathrm{a}^{-1}$ sample volumes must be between 50 and 2001 of water. This means the collection of up to $0.6 \mathrm{~m}^{3}$ of snow/firn at each site.

We collected snow from two types of site. The first, and preferable, one was from the tops of the larger ice caps of the Queen Elizabeth Islands (Fig.1 and Table I). A corer was used at these sites to take $76 \mathrm{~mm}$ diameter cores representing several years of accumulation. The snow accumulation rate at each site is known from earlier work (Koerner 1979). Therefore, the length of cores needed to give multi-year samples can be calculated. Cores were drilled at level sites, distant from nunataks. The cores, together with all the ice chips, were transferred directly from the core barrel to large, clear plastic bags. Several bags of cores were collected at each site and transported, in a frozen condition, back to Resolute Bay by Twin Otter aircraft. Cores from Agassiz Ice Cap (Fig.1: site 7) were processed at the site.

The second type of site lies in areas where only the current surface snow layer can be sampled. These sites are in the western high Arctic, on the floating ice of the Arctic Ocean, and in northern Greenland (Figure 1 and Table I). At these sites the snow generally melts completely in summer. The snow layer represents the period from the end of melting in the fall to the time of sampling which, in most cases, is the following May. These samples were collected by transferring snow from pits to clean plastic bags with a clean shovel. Care was 


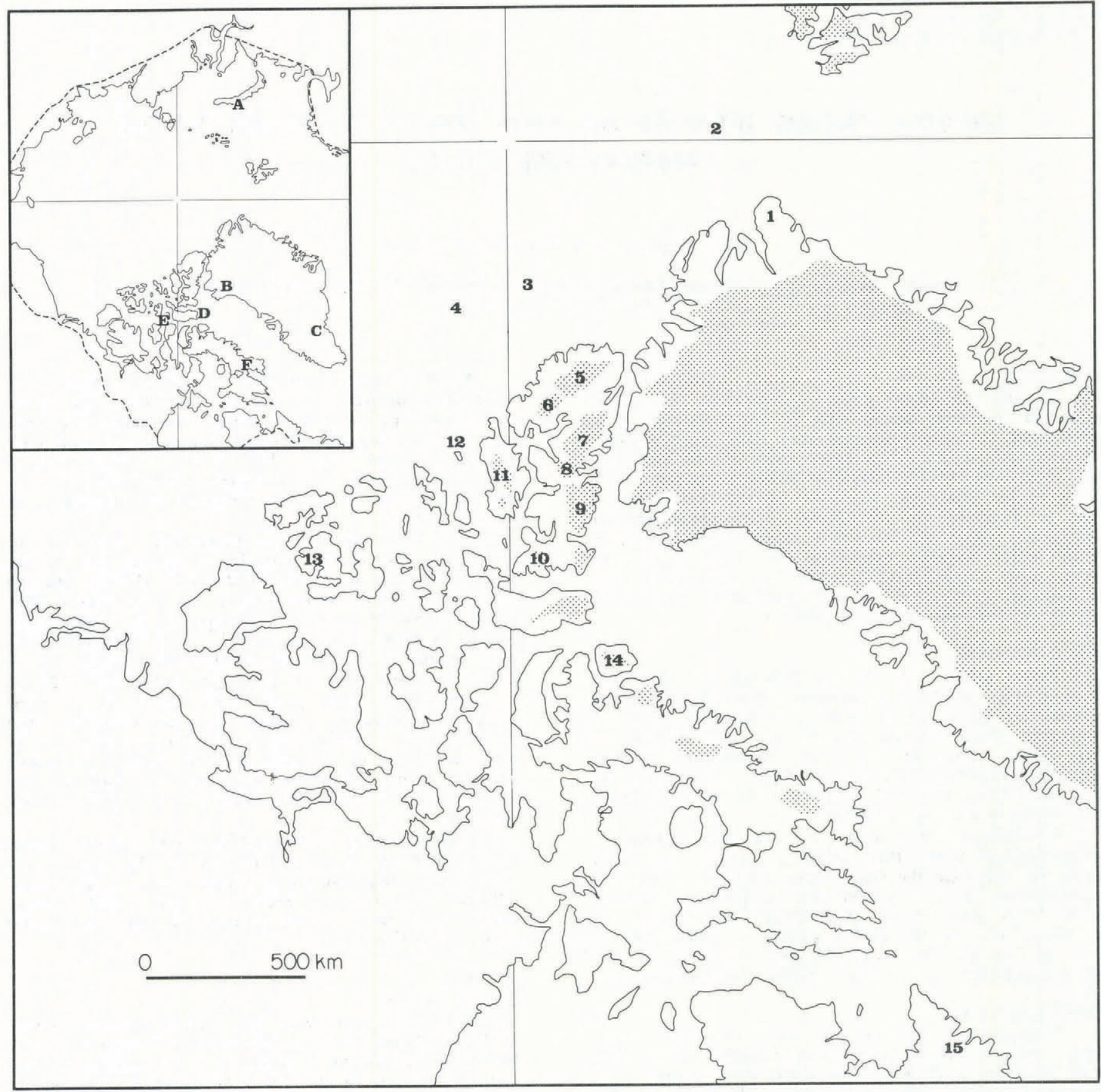

Fig.l. Location map. The numbers correspond to the pollen sampling sites and are explained in Table I. Shaded areas represent ice caps. The letters in the inset map refer to locations mentioned in the text: A Vavilov ice cap (Novaya Zemlya), B Camp Century, C Dye-3, D Devon Island ice cap, E Resolute Bay, F Penny Ice Cap. The hatched line represents the approximate northern limit of trees.

taken to make the pit walls vertical to avoid seasonal bias.

Clean metal pots were used to melt the samples over a propane stove. A known number of Lycopodium spores were injected into the melted sample before filtering. These spores are counted along with the filtered pollen in the final microscope procedure and allow calculation of pollen grain loss during sample preparation. $47 \mathrm{~mm}$ cellulose nitrate filters with a pore size of $8 \mu \mathrm{m}$ were used to filter the meltwater. These filters allow most of the siliceous microparticles to pass through while retaining all the pollen grains and spores.

Procedural blanks were made by exposing filtered water to the air throughout the filtering procedure. These blanks were later processed and showed that air from the field laboratory contributed less than $1 \%$ of the total pollen counted.

\section{Laboratory method}

Because of the very low concentrations of pollen in our samples, we found the traditional methods (Faegri and Iverson 1975) of sample preparation, which includes decanting a centrifuged sample, unsatisfactory. To minimise loss of pollen during sample preparation a new method was developed for use in our laboratory in Ottawa.

The sample filter from the field is left in hydrofluoric acid overnight to dissolve any remaining siliceous microparticles. An infrared lamp is sometimes used to speed up the procedure. The mixture is then passed through a Nuclepore filter which retains all the pollen grains on its surface rather than within a fibre matrix as with many other filter types. An acetolysis procedure ( 9 parts acetic anhydride, 1 part sulphuric acid) is then used to stain the pollen grains and dissolve the cellulose nitrate filter. The Nuclepore filter is cut in 
TABLE I. POLLEN SUM SAMPLE VOLUMES, NUMBER OF YEARS REPRESENTED BY SAMPLES AND ACCUMULATION RATES AT EACH SITE

\begin{tabular}{|c|c|c|c|c|c|}
\hline Site & number and name & $\begin{array}{l}\text { Pollen } \\
\text { sum }\end{array}$ & $\underset{\text { (1) }}{\text { Volume }}$ & $\begin{array}{c}\text { Number of } \\
\text { years }\end{array}$ & $\begin{array}{l}\text { Accumulation rate } \\
\qquad\left(\mathrm{kg} \mathrm{m}^{-2} \mathrm{a}^{-1}\right)\end{array}$ \\
\hline $1^{*}$ & Nord & 430 & 88.8 & $<1$ & 150 \\
\hline $2^{*}$ & White Dwarf & 287 & 79.4 & $<1$ & 200 \\
\hline $3^{*}$ & Transglobe & 258 & 20.8 & $<1$ & 150 \\
\hline 4* & CESAR & 1055 & 71.3 & $<1$ & 150 \\
\hline 5 & Mount Oxford (a) & 80 & 155.1 & approx. 15 & 160 \\
\hline 5 & Mount Oxford (b) & 268 & 77.8 & approx. 15 & 160 \\
\hline 6 & "Otto Ice Cap" & 728 & 73.8 & approx. 12 & 200 \\
\hline 7 & Agassiz Ice Cap (North) & 540 & 77.8 & approx. 12 & 175 \\
\hline 8 & Agassiz Ice Cap (South) & 440 & 110.9 & approx. 8 & 327 \\
\hline 9 & Prince of Wales Ice Cap & 450 & 81.8 & approx. 8 & 320 \\
\hline 10 & Sydkap Ice Cap & 387 & 70.1 & 3 & 335 \\
\hline 11 & Müller Ice Cap & 879 & 62.5 & approx. 15 & 157 \\
\hline $12 *$ & Meighen Ice Cap & 371 & 40.9 & $<1<$ & 187 \\
\hline $13^{*}$ & $\begin{array}{l}\text { Melville Island } \\
\text { "South Ice Cap" }\end{array}$ & 872 & 43.2 & $<1$ & 174 \\
\hline 14 & Bylot Island Ice Cap & 291 & 31.8 & 3 & 220 \\
\hline $15^{*}$ & Torngat Mountains & 216 & 1.1 & 1 & 700 \\
\hline
\end{tabular}

* Samples collected by other groups, listed in acknowledgements.

TABLE II. LIST OF TAXA, TOTALS AND CONCENTRATIONS PER LITRE FOR EACH SITE

Pinus (pine)

Picea (spruce)

Betula (birch)

Alnus (alder)

Other trees (-Salix)

Ambrosia (ragweed)

Artemisia (sage)

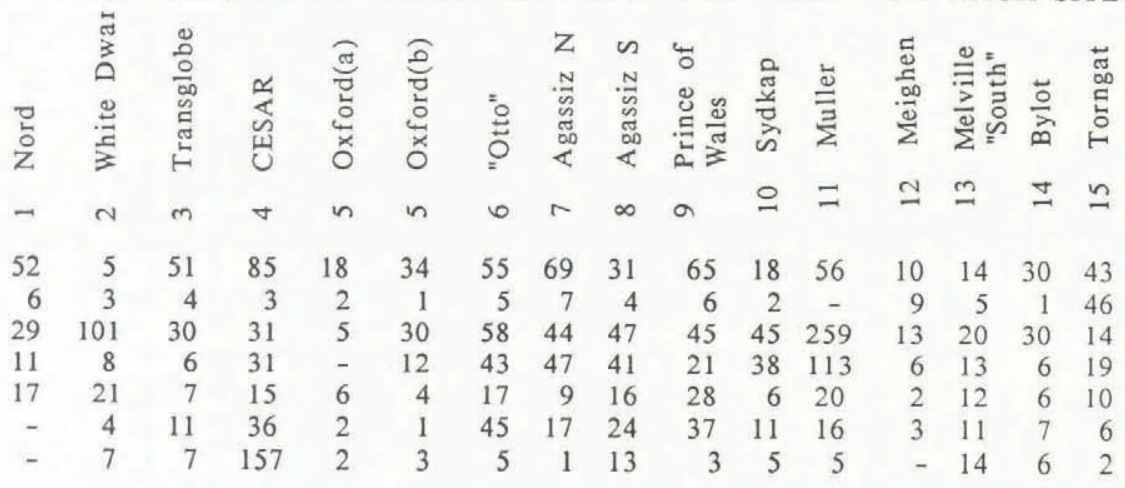

Exotic E

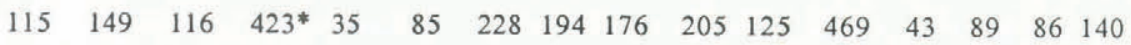

Concentration

$\begin{array}{llllllllllllllll}1.3 & 1.9 & 5.6 & 5.9 & 0.2 & 1.2 & 3.1 & 2.5 & 1.6 & 2.5 & 1.8 & 7.5 & 1.1 & 2.1 & 2.7 & 126.1\end{array}$

per litre

Salix (willow)

Ericaceae

Gramineae

Cyperaceae

Saxif ragaceae

Oxyria (sorrel)

Other herbs

Pteridophyta

$\begin{array}{rrrrrrrrrrrrrrrr}6 & 7 & 19 & 53 & 3 & 38 & 108 & 100 & 27 & - & 16 & 36 & 6 & 25 & - & 2 \\ 6 & 5 & 2 & - & - & 3 & 4 & 5 & 4 & 6 & 14 & 6 & 1 & 3 & 3 & 5 \\ 11 & 15 & 19 & 185 & 2 & 43 & 123 & 62 & 31 & 38 & 41 & 63 & 70 & 175 & 14 & 3 \\ 6 & - & 23 & 26 & 6 & 21 & 41 & 20 & 17 & 13 & 9 & 43 & 15 & 10 & 10 & 2 \\ 11 & 5 & 7 & 8 & - & 8 & 24 & 26 & 6 & 4 & 13 & 9 & 7 & 20 & - & 1 \\ 6 & 15 & 13 & 7 & 2 & 11 & 43 & 25 & 19 & 3 & 11 & 17 & 7 & 6 & 1 & - \\ 12 & 27 & 21 & 52 & 13 & 16 & 49 & 40 & 44 & 33 & 23 & 47 & 13 & 56 & 12 & 4 \\ 22 & 6 & 8 & 24 & 3 & 9 & 6 & 6 & 3 & 25 & 10 & 11 & 23 & 40 & 23 & 23\end{array}$

Regional $\Sigma$

Concentration

per litre

$\begin{array}{llllllllllllllll}80 & 80 & 112 & 355 & 29 & 149 & 398 & 284 & 151 & 122 & 137 & 232 & 142 & 335 & 63 & 40\end{array}$

$\begin{array}{llllllllllllllll}0.9 & 1.0 & 5.3 & 5.0 & 0.2 & 2.0 & 5.4 & 3.7 & 1.4 & 1.5 & 2.0 & 3.7 & 3.5 & 7.8 & 2.0 & 36.0\end{array}$

$\begin{array}{lllllllllllllllll}\text { Sphagnum } & - & 4 & - & 198 & 2 & 7 & 23 & 16 & 59 & 56 & 63 & 133 & 158 & 399 & 119 & 26\end{array}$

$\begin{array}{lllllllllllllllll}\text { Unknown } & 17 & 11 & 4 & 30 & 3 & 3 & 20 & 7 & 14 & 11 & 21 & 11 & 7 & 13 & 6 & 5\end{array}$

$\begin{array}{lllllllllllllllll}\text { Indeterminate } & 218 & 43 & 21 & 49 & 11 & 24 & 59 & 39 & 40 & 56 & 41 & 34 & 21 & 36 & 17 & 5\end{array}$

Total $\Sigma$

Litres

$\begin{array}{llllllllllllllll}430 & 287 & 253 & 1055 & 80 & 268 & 728 & 540 & 440 & 450 & 387 & 879 & 371 & 872 & 291 & 216\end{array}$

Concentration

per litre

$\begin{array}{lllllllllllllllll}88.8 & 79.4 & 20.8 & 71.3 & 155.1 & 73.8 & 73.8 & 77.8 & 110.9 & 81.8 & 70.1 & 62.5 & 40.9 & 43.2 & 31.8 & 1.1\end{array}$

$\begin{array}{llllllllllllllll}4.8 & 3.6 & 12.2 & 14.8 & 0.5 & 3.6 & 9.9 & 6.9 & 4.0 & 5.5 & 5.5 & 14.1 & 9.1 & 20.2 & 9.2 & 194.6\end{array}$

*65 Chenopodiaceae are also listed in the "exotic" sum at this site. 


\begin{tabular}{|c|c|c|c|c|c|c|c|c|c|c|c|c|c|c|c|c|}
\hline & $\begin{array}{l}\text { Dे } \\
\text { Z }\end{array}$ & 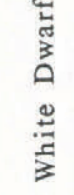 & 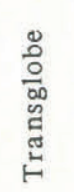 & 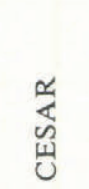 & 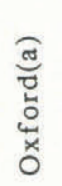 & 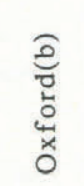 & $\begin{array}{l}=0 \\
\text { OO⿱艹冖) } \\
0\end{array}$ & 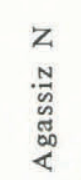 & $\begin{array}{l}n \\
N \\
n \\
n \\
0 \\
\infty \\
\infty \\
\infty\end{array}$ & 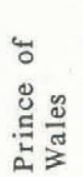 & $\begin{array}{l}\frac{0}{\tilde{z}} \\
\frac{\vec{z}}{\vec{n}}\end{array}$ & $\stackrel{\overrightarrow{0}}{\stackrel{3}{3}}$ & 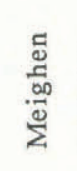 & 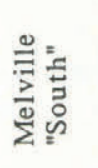 & $\frac{\overrightarrow{0}}{\grave{\lambda}}$ & 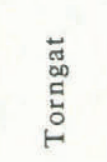 \\
\hline & - & $N$ & $m$ & $\nabla$ & $n$ & $n$ & 0 & r & $\infty$ & $a$ & 으 & $=$ & $\simeq$ & $\cong$ & $\Xi$ & $\cong$ \\
\hline Pinus & 88 & 13 & 367 & 179 & 19 & 74 & 149 & 155 & 91 & 254 & 86 & 141 & 46 & 56 & 208 & 27,364 \\
\hline Picea & 10 & 8 & 29 & 6 & 2 & 2 & 14 & 16 & 12 & 23 & 10 & - & 41 & 20 & 7 & 29,273 \\
\hline Betula & 50 & 254 & 216 & 65 & 5 & 65 & 157 & 99 & 139 & 176 & 215 & 651 & 59 & 80 & 208 & 8,909 \\
\hline Alnus & 19 & 20 & 43 & 65 & - & 26 & 116 & 106 & 121 & 82 & 182 & 284 & 27 & 52 & 42 & 12,091 \\
\hline $\begin{array}{l}\text { Other trees } \\
\text { (-Salix) } \\
\text { Ambrosia } \\
\text { Artemisia }\end{array}$ & $\begin{array}{r}29 \\
- \\
-\end{array}$ & $\begin{array}{l}51 \\
10 \\
18\end{array}$ & $\begin{array}{l}50 \\
79 \\
50\end{array}$ & $\begin{array}{r}33 \\
76 \\
330\end{array}$ & $\begin{array}{l}5 \\
2 \\
2\end{array}$ & $\begin{array}{l}9 \\
2 \\
7\end{array}$ & $\begin{array}{r}49 \\
122 \\
14\end{array}$ & $\begin{array}{r}20 \\
38 \\
2\end{array}$ & $\begin{array}{l}44 \\
71 \\
38\end{array}$ & $\begin{array}{r}109 \\
145 \\
12\end{array}$ & $\begin{array}{l}29 \\
53 \\
24\end{array}$ & $\begin{array}{l}50 \\
40 \\
13\end{array}$ & $\begin{array}{r}8 \\
14 \\
-\end{array}$ & $\begin{array}{l}56 \\
44 \\
56\end{array}$ & $\begin{array}{l}42 \\
48 \\
42\end{array}$ & $\begin{array}{l}6,364 \\
3,818 \\
1,273\end{array}$ \\
\hline Total exotic & 194 & 373 & 835 & $890^{*}$ & 35 & 184 & 620 & 436 & 516 & 802 & 598 & 1178 & 196 & 366 & 596 & 88,368 \\
\hline Salix & 10 & 18 & 137 & 112 & 3 & 82 & 293 & 225 & 80 & - & 76 & 90 & 27 & 101 & - & 1,273 \\
\hline $\begin{array}{l}\text { Ericaceae } \\
\text { Gramineae }\end{array}$ & 10 & 13 & 14 & - & - & 7 & 11 & 11 & 12 & 23 & 67 & 15 & 5 & 12 & 21 & 3,182 \\
\hline $\begin{array}{l}\text { Gramineae } \\
\text { Cyperaceae }\end{array}$ & 19 & 38 & 137 & 389 & 2 & 93 & 333 & 139 & 91 & 149 & 196 & 158 & 320 & 705 & 97 & 1,909 \\
\hline $\begin{array}{l}\text { Cyperaceae } \\
\text { Saxifragaceae }\end{array}$ & 10 & - & 166 & 55 & 6 & 46 & 111 & 45 & 50 & 51 & 43 & 108 & 69 & 40 & 69 & 1,273 \\
\hline $\begin{array}{l}\text { Saxif ragaceae } \\
\text { Oxyria }\end{array}$ & 19 & 13 & 50 & 17 & - & 17 & 65 & 58 & 18 & 16 & 62 & 23 & 32 & 81 & - & 636 \\
\hline $\begin{array}{l}\text { Oxyria } \\
\text { Other herbs }\end{array}$ & 10 & 38 & 94 & 15 & 2 & 24 & 117 & 56 & 57 & 12 & 53 & 43 & 32 & 24 & 7 & - \\
\hline $\begin{array}{l}\text { Other herbs } \\
\text { Pteridophyta }\end{array}$ & $\begin{array}{l}20 \\
37\end{array}$ & $\begin{array}{l}68 \\
15\end{array}$ & $\begin{array}{r}151 \\
58\end{array}$ & $\begin{array}{r}109 \\
50\end{array}$ & $\begin{array}{r}13 \\
3\end{array}$ & $\begin{array}{l}35 \\
20\end{array}$ & $\begin{array}{r}133 \\
16\end{array}$ & $\begin{array}{l}90 \\
13\end{array}$ & 130 & 129 & 110 & 118 & 59 & 226 & 83 & 2,545 \\
\hline $\begin{array}{l}\text { Total } \\
\text { regional }\end{array}$ & 135 & 202 & 806 & 747 & 30 & 323 & 1078 & 641 & 445 & 475 & 653 & 583 & 647 & 1357 & 436 & 25,248 \\
\hline
\end{tabular}

\begin{tabular}{lrrrrrrrrrrrrrrrrr}
\hline Sphagnum & - & 10 & - & 417 & 2 & 15 & 62 & 36 & 174 & 219 & 301 & 334 & 722 & 1607 & 823 & 16.545 & 45 \\
Unknown & 29 & 28 & 29 & 63 & 3 & 7 & 54 & 16 & 41 & 43 & 100 & 28 & 32 & 52 & 42 & 3,182 & 82 \\
Indeterminate & 368 & 108 & 151 & 103 & 11 & 52 & 160 & 88 & 118 & 219 & 196 & 85 & 96 & 145 & 118 & 3,182 & \\
\hline
\end{tabular}

Total pollen

$\begin{array}{lllllllllllllllll}\begin{array}{l}\text { Total pollen } \\ \text { and spores }\end{array} & 726 & 721 & 1821 & 2220 & 83 & 581 & 1973 & 1215 & 1297 & 1760 & 1849 & 2208 & 1696 & 3512 & 2013 & 137,455\end{array}$

*137 Chenopodiaceae are included in "total exotic" at this site.

Note: totals may not equal the sum of individual pollen types due to rounding off the individual values shown in the Table.

two for mounting. A few drops of glycerine are added to the mounted filter which is then covered with a 220 x $600 \mathrm{~mm}$ cover glass.

All laboratory procedures are carried out in a Class-100 clean-air cabinet. Vacuum-drawn samples taken at various times in the laboratory, away from the air-cleaning facilities, showed the laboratory air to be pollen - free.

\section{RESULTS}

We should emphasize that the data for all but one site consist of from 200 to over 1000 pollen grains per site (Table I). The one exception (Fig.1: site 5) is represented by 80 grains. However, a second core was taken, $1 \mathrm{~km}$ from the original site and yielded over 200 grains (Tables I and II, Figs. 2(a) and (b)).

Our method generates data in terms of pollen grain/spore concentrations per litre of melted sample. These values are converted to deposition rates in grains $\mathrm{m}^{-2} \mathrm{a}^{-1}$ by multiplying the concentration values by the accumulation rate $\left(\mathrm{kg} \mathrm{m}^{-2} \mathrm{a}^{-1}\right)$ at each site (Table I). The various deposition rates are listed in Table III. The regional and exotic pollen totals for each site are shown in Figures 2(a) and (b). The average total pollen-grain deposition rate for the high Arctic (which includes exotic, regional, unknown and indeterminate grains and Sphagnum spores) is $1.6 \times 10^{3}$ grains $\mathrm{m}^{-2} \mathrm{a}^{-1}$. The average for exotic pollen is $0.5 \times 10^{3}$ grains $\mathrm{m}^{-2} \mathrm{a}^{-1}$ and for regional pollen grains is $0.6 \times 10^{3}$ grains $\mathrm{m}^{-2} \mathrm{a}^{-1}$.

To extend the discussion to include areas south of the tree line, values from table IV of Ritchie and Lichti-Federovich (1967) have been taken for pollen types exotic to the high Arctic (see our Table II) and expressed in terms of annual deposition rates. The most striking feature of the exotic pollen distribution is the steep concentration gradient between the northern edge of the pollen source and the deposition site. There is a drop from $8.5 \times 10^{6}$ grains $\mathrm{m}^{-2} \mathrm{a}^{-1}$ at the tree line in northern Ungava (mean value for Great Whale River, Fort Chimo and Knob Lake) to our value of $8.8 \times 10^{4}$ grains $\mathrm{m}^{-2} \mathrm{a}^{-1}$ in the glacierized parts of the Torngat Mountains (Fig.1: site 15 and Fig.2(a)) just tens of kilometres beyond the tree line. Deposition rates then drop two orders of magnitude between the Torngats and the southern part of the high Arctic. In the western Arctic, over a much shorter distance (Fig.1), the drop between the tree line and the southern high Arctic is from deposition rates of $3.1 \times 10^{6}$ grains $\mathrm{m}^{-2} \mathrm{a}^{-1}$ (mean 

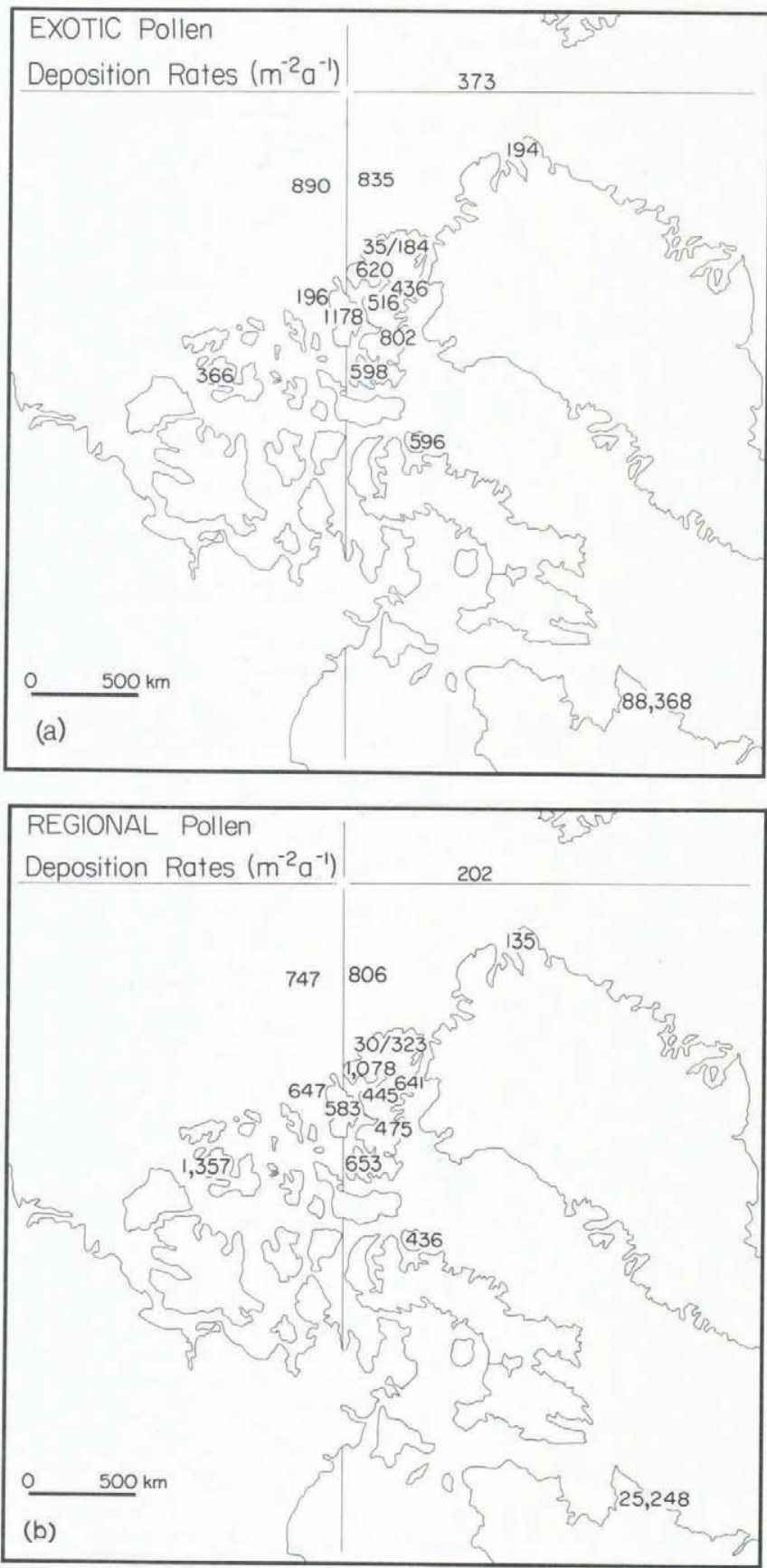

Fig.2. Exotic (a) and regional (b) pollen deposition rates. The values between the North Pole and northern Ellesmere Island (835) are the means of several samples collected by the British Transglobe Expedition between those two locations.

value for Inuvik, Coppermine and Ennadai Lake) to $0.4 \times 10^{3}$ grains $\mathrm{m}^{-2} \mathrm{a}^{-1}$ on southern Melville Island (Fig.1: site 13 and Fig.2(a)). In the region north of and including, the Bylot and Melville island sites (Fig.1: sites 13 and 14 and Fig. 2(a)) and on the adjacent Arctic Ocean there is no further significant decrease in pollen deposition rates.

There are some anomalously high and low concentrations of individual species at certain sites. The furthest north site on land, Mount Oxford (Fig.1: site 5 and Fig.2(a)), shows the lowest pollen concentrations of all sites regardless of species. There is a very high concentration of Artemisia and, although not listed, Chenopodiaceae, on one Arctic Ocean site (Fig.1: site 4 and Fig.2(a)). There are similarly high concentrations of Betula and, to a lesser extent, Alnus on Müller Ice Cap (Fig.1: site 11 and Fig.2(a)). Finally, we draw attention to the concentrations of Pinus compared to Picea; both have similar source areas. In northern Ungava, where
TABLE IV. EXOTIC POLLEN CONCENTRATIONS IN SNOW, DEVON ISLAND ICE CAP, MAY 1973

\begin{tabular}{lr}
$\begin{array}{l}\text { Concentration } \\
\left(\mathrm{x} 10^{-2} \mathrm{~kg}^{-1}\right)\end{array}$ & $\begin{array}{c}\text { Depth in sno } \\
(\mathrm{m})\end{array}$ \\
\hline & $0-0.1$ \\
$138^{*}$ & $0.1-0.2$ \\
135 & $0.2-0.3$ \\
74 & $0.3-0.4$ \\
45 & $0.4-0.5$ \\
35 & $0.5-0.6$ \\
$3 * *$ &
\end{tabular}

* April-May 1973 snow layer.

** summer 1972 layer, slight melting.

the Picea and Pinus tree lines are most widely separated, Picea pollen exceeds Pinus pollen by 50:1 (Ritchie and Lichti-Federovich 1967). However, only a short distance to the north the ratio approaches $1: 1$ even at the Picea tree line in some cases (Ritchie and Lichti-Federovich 1967). In the high Arctic, Pinus pollen dominates Picea pollen by about 10:1. It would appear from this data that using the Picea : Pinus ratio to determine the source region could be misleading.

\section{DISCUSSION}

The values shown in Tables II and III and Figures 2(a) and (b) include three basic types of variability: annual, regional and local.

Annual variability complicates comparisons between sites represented by surface snow samples as these are accumulations of slightly less than one year and not all of the samples were taken in the same year. Thus the high concentration of Artemisia at site 4 on the Arctic Ocean (Fig.1 and Table III) may be an example of annual noise. Core sites represent several years of accumulation so that annual variability is substantially reduced in them. Hence we cannot explain the high concentration of Betula and, to a lesser extent, Alnus on Müller Ice Cap (Fig.1: site 11 and Table III) in terms of annual variability. In fact at present we have no satisfactory explanation for such high concentrations.

Regional variability may be due either to topographic differences between sites or to differences of site location with respect to general air circulation. The very low pollen deposition rate at one of the Mount Oxford sites (Fig.1: site 5 and Fig.2) is a good example of the topographic -effect. The snow at a similar ridge-top site on Agassiz Ice Cap (Fig.1: site 7) has already been shown to have anomalously high oxygen isotope values due to scouring of the winter snow layer (Fisher and others 1983). We will explain later that it is this layer that probably contains most of the pollen, so we may be seeing a similar scouring effect on Mount Oxford. A second set of core samples downslope of the original set has in fact shown significantly higher pollen concentrations.

Local variability applies within areas less than 1 $\mathrm{km}$ apart and is due to variations in the way that snow and pollen accumulate and move in response to each individual storm. We have no measure of such local variability yet but do not believe it is large enough to disturb the orders-of-magnitude variations in rates of pollen deposition that we discuss in this paper.

\section{REGIONAL DISTRIBUTION OF POLLEN}

The process of production, transport and incorporation of pollen into snow deposits in the high 


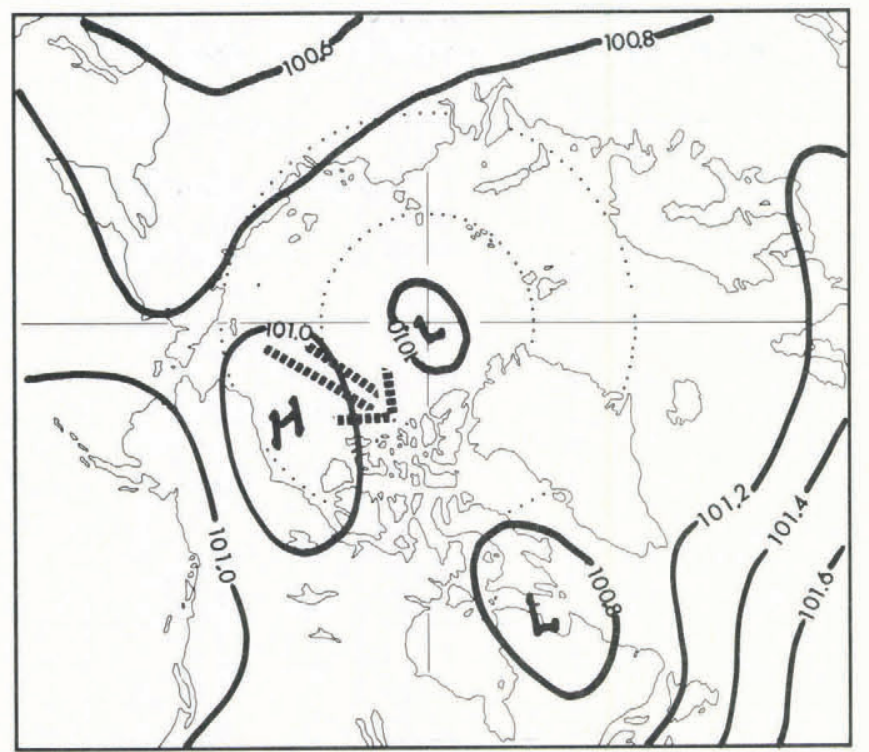

(a)

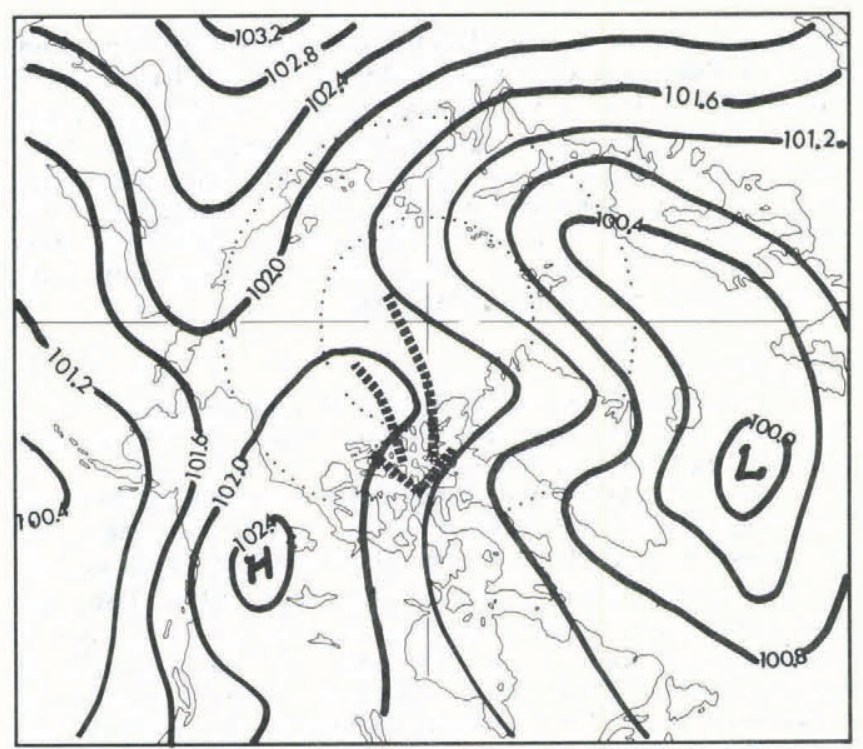

(c)

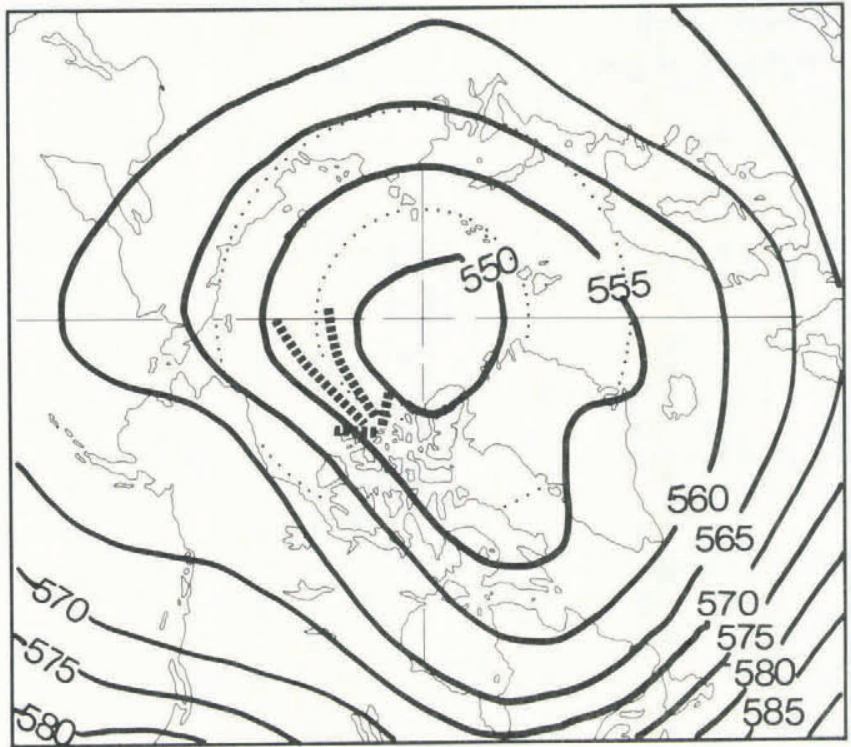

(b)

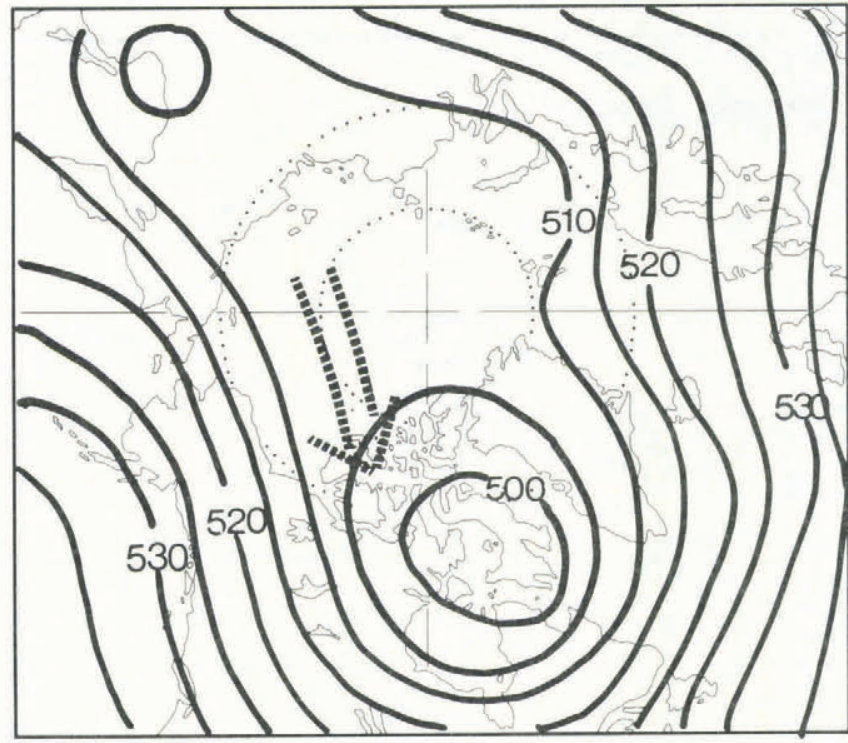

(d)

Fig.3. (a) Summer (July) mean surface pressure ( $\mathrm{kPa}$ ) 1949-1978 ( $\mathrm{T}$ Jakobssen personal communication). Arrow indicates generalized direction of flow.

(b) Summer (July) mean $50 \mathrm{kPa}$ height contours (m x 10), 1949-1978 ( $\mathrm{T}$ Jakobssen personal communication). Arrow indicates generalized direction of flow.

(c) Winter (January) surface mean pressure $(\mathrm{kPa})$ composite from various sources (from Prik, after Orvig 1970). Arrow indicates generalized direction of flow.

(d) Winter (January) mean $50 \mathrm{kPa}$ height contours $(\mathrm{m} \times 10)$ schematic composite (from Prik, after Orvig 1970). Arrow indicates generalized direction of flow.

Arctic is a complicated one, especially in the case of exotic species. However, we have ample evidence for straight-line transport distances of at least $3000 \mathrm{~km}$ (e.g. for pollen from southern Canada such as Ambrosia). In general, the distances are of the order of 1000 to 2500 $\mathrm{km}$. The actual transport distances must be considerably longer; otherwise we would see gradients of deposition rates within the high Arctic region and we do not (Figs. 2(a) and (b)).

\section{Exotic pollen}

The steep exponential decrease in deposition rates of exotic pollen between the North American tree line and the high Arctic warrants discussion. This decay pattern is not a simple south-north one (i.e. meridional) and does not reflect direct northward transport of aerosols.

The steepest decrease in deposition rates of exotic pollen is between the tree line and the western high Arctic sites (Fig.1: site 13). This gradient may be explained by examining the mean atmospheric circulation conditions shown in Figures 3(a), (b), (c) and (d). In both the summer and the winter, at the surface and at upper levels, the mean flow into the Melville Island region is from the north-west sector. The north-westerly flow dominates the Arctic islands as far south and east as Bylot Island (Fig.1: site 14) which has pollen deposition rates similar to the other high Arctic sites in the west. Thus we see why the mean flow at all levels in the troposphere does not support direct transport of pollen into the high Arctic from the tree-line sources directly to the south.

While some pollen grains have a diameter as large as $100 \mu \mathrm{m}$, their structure and shape makes them extremely buoyant. Thus when discussing transport of pollen grains, particularly in the low concentrations 


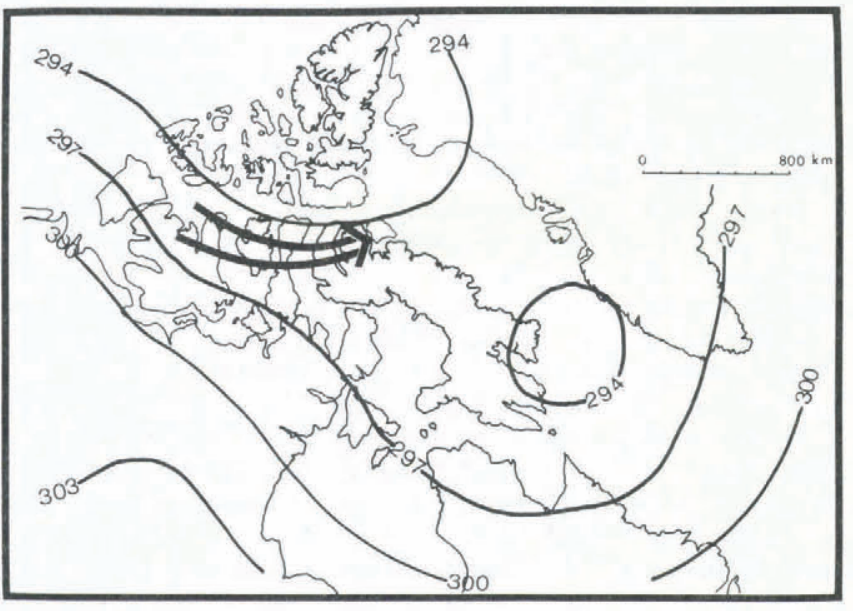

Fig.4. Mean July $70 \mathrm{kPa}$ height contours (m $\mathrm{x}$ 10) (after Maxwell 1980). Arrow indicates flow into the Bylot Island area.

measured in the high Arctic, it is necessary to consider atmospheric levels up to at least $50 \mathrm{kPa}$ (about $6000 \mathrm{~m}$ ). For example, Holdsworth (personal communication) has found pollen in cores collected from the $5400 \mathrm{~m}$ level on Mount Logan in Yukon Territory. It is also necessary to consider the unique nature of the circulation within the cold-core westerly circumpolar vortex which dominates the Canadian high Arctic (Maxwell 1980). We may explain the sustained pollen deposition rates over the central Arctic Ocean in terms of the characteristics of the mean high Arctic circulation (Alt 1985) as follows. Pollen can be carried by, and washed out of, non-frontal lows which extend from the surface to 50 $\mathrm{kPa}$ and move slowly across the central Arctic Ocean (Fig.5). In addition to wash out in non-frontal lows, large-scale subsidence in conditions of shallow surface anticyclonic circulation, shown in Figures 3(a) and (c), encourages dry fallout of pollen brought in at quite high levels of the atmosphere. The intrusion of mid-latitude frontal storms into the domain of the circumpolar vortex is an important feature of the high Arctic synoptic regime which is not represented by the mean pressure patterns discussed here. They may play a significant part in the transport of pollen and other aerosols and require further study.

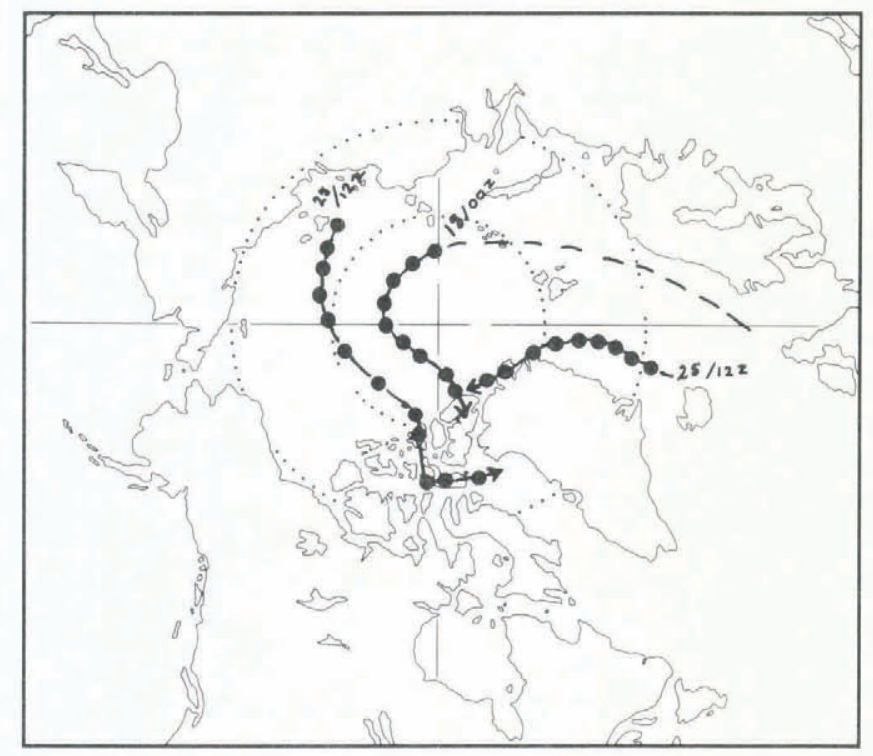

Fig.5. Examples of storm tracks into the Canadian high Arctic (Maxwell personal communication) from reanalyzed charts for July 1964. Dots represent the position of a surface low every $12 \mathrm{~h}$ beginning 1200 GMT, 25 July 1964.

\section{Regional pollen}

The deposition rates of regional pollen types for each site are listed in Table III. Proximity to nearby tundra sources may explain the high regional rates of pollen deposition on the Melville Island ice cap site (Fig.1: site 13 and Fig.2(b)). However, quite high deposition rates over the Arctic Ocean (Fig.2 (a) and (b)) suggest that even these regionally produced pollen types can be widely dispersed.

\section{SEASONAL DISTRIBUTION OF EXOTIC POLLEN}

While we have variations of pollen deposition rates regionally due to the nature of atmospheric circulation, we also see variations in the pollen concentrations of snow layers at any one site from season to season. If we recalculate the snow-pit data from the Devon Island ice cap in table I of Lichti-Federovich (1974) in terms of pollen concentrations in the snow we find that the concentration of exotic pollen increases as winter progresses (Table IV). The layer at the bottom of the pit profile shows evidence of melting; it therefore represents the warmest period of the 1972 summer, yet it contains almost no exotic arboreal pollen. Most high Arctic profiles, whether of soluble or insoluble materials in the snow, show similar seasonal variations. Low autumn values increase through winter to a spring peak and then drop back to low summer values (Koerner and Fisher 1982). We will consider three mechanisms that contribute to such a seasonal variation of pollen concentrations in a high Arctic snowpack.

The first mechanism relates to seasonal movement of the Arctic Front which is often considered to form a barrier to meridional transport (Bryson 1966). McAndrews (1984) attributes the almost complete dominance of pollen from Arctic plants in Arctic air masses in summer (the season of major arboreal pollen productivity) to the presence of the Arctic Front along the tree line in that season prohibiting the northward transport of arboreal pollen. Rahn and McCaffrey (1980) have explained relatively high concentrations of anthropogenic aerosols in winter at Barrow, Alaska as due to movement southwards of the Arctic Front in winter. This movement extends the source area beyond the tree line and, in the case of pollutants, far enough south to incorporate large industrial sources of pollution. While winter is not a season of pollen production, Janzon (1981), working in Stockholm, has shown that pollen is available for re-entrainment within the source region during this season. However, southward movement of the Arctic Front, while it may expand the source area, does not necessarily make that area more accessible to the high Arctic.

A second, and very important, effect on pollen concentration in the snow, is seasonal variations of synoptic weather patterns in the Arctic (Figs.3 and 4). For example, the summer circulation pattern shown in Figure 4 does not support pollen influx to the high Arctic at a time when pollen production south of the tree line is at a maximum. In fact there is a very low pollen concentration in the summer snow layer on the Devon Island ice cap (Table IV) indicating conditions of exotic pollen drought in summer in the high Arctic.

Finally, there is the effect of seasonal variations in the rate of precipitation both over the site and between the pollen source and deposition site. Snow stratigraphy studies (Koerner 1966) have shown that the winter snow accumulation rate on Devon Island ice cap is only about 1 or $2 \mathrm{~mm} \mathrm{~d}^{-1}$ compared to 3 to $10 \mathrm{~mm}$ $\mathrm{d}^{-1}$ in autumn and summer. Records from permanent weather stations show that such a seasonal precipitation distribution is quite typical of the Arctic. Because wash-out is probably an important mechanism of pollen removal from the atmosphere (Schmidt 1973), more pollen is washed out en route between source and site during the seasons with higher precipitation. That is, autumn and summer snow layers have low concentrations of exotic pollen because less exotic pollen reaches the high Arctic during those seasons.

Pollen concentration in the snow must also be related to the precipitation rate at the site. In this case 
heavy snowfall dilutes the pollen concentration in the accumulating snowpack to reduce even further the depleted concentrations of pollen in snow layers deposited in the warmer months.

\section{CONCLUSIONS}

While our work on the present-day distribution of pollen deposition rates is far from complete, it has so far been possible to show that there is a steep exponential decay of pollen deposition rates north of the tree line and an absence of deposition rate gradients within the circumpolar vortex which covers the Arctic islands and most of the central part of the Arctic Ocean. We do not see pollen transport in the atmosphere as a simple meridional feature (cf. Barry and others 1981).

The absence of any detectable trend in pollen deposition rates within the Arctic islands extends onto the sea ice of the Arctic Ocean, possibly as far as and beyond the North Pole, but certainly across the north coast of Greenland up to our furthest sampling point close to Svalbard (Fig.1: site 2). The extent of this apparently trendless region coupled with the characteristics of the general circulation may mean that some of the pollen entering the Arctic islands may have an Eurasian source. The flatness of the distribution suggests long trajectories and complete mixing of pollen from different source areas.

Although exotic pollen deposition rates are as low as $0.5 \times 10^{3}$ grains $\mathrm{m}^{-2} \mathrm{a}^{-1}$, further study of the regional distribution of these rates and assemblages should lead to a better understanding of air mass circulation and dispersion of aerosols in the high Arctic.

\section{ACKNOWLEDGEMENTS}

We would like to thank the following for the collection of samples from the sites shown in Figure 1: A Gill (sites 1 and 2), L Lundgaard (sites 4, 12 and 13), Sir Ranulph Fiennes (a series between northern Ellesmere Island and the North Pole, summarised as site 3) and Dr R Rogerson (site 15). We would also like to acknowledge the encouragement of $G$ Hobson (Director, PCSP) who first pointed out to us the potential of pollen studies. We greatly appreciate the critical reviews of an early draft by Drs $J$ V Mathews and L Barrie.

\section{REFERENCES}

Alt B T 1985 Atmospheric circulation in the Canadian high Arctic. Annals of Glaciology 7: 213

Barry R G, Elliott D L, Crane R G 1981 The paleoclimatic interpretation of exotic pollen peaks in Holocene records. Review of Palaeobotany and Palynology 33: 153-167

Bryson R A 1966 Air masses, streamlines and the boreal forest. Geographical Bulletin 8: 228-269

Elliot-Fisk D L, Andrews J T, Short S K, Mode W N 1982 Isopoll maps and an analysis of the modern pollen rain, eastern and central northern Canada. Géographie Physique et Quaternaire 36(1-2): 91-108

Fægri K, Iverson J 1975 Textbook of pollen analysis. Copenhagen, Munksgaard

Fisher D A, Koerner R M, Paterson W S B, Dansgaard W, Gundestrup N, Reeh N 1983 Effect of wind scouring on climatic records from ice-core oxygen-isotope profiles. Nature 301(5897): 205-209

Fredskild B, Wagner P 1974 Pollen and fragments of plant tissue in core samples from the Greenland ice cap. Boreas 3(3): 105-108

Gregory P H 1978 Distribution of airborne pollen and spores and their long distance transport. Pure and Applied Geophysics 116(2-3): 309-315

Janzon L-A 1981 Airborne pollen grains under winter conditions. Grana 20: 183-185

Kalugina L V, Malakhovskiy D B, Makeyev V M, Safronova I N 1979 Nekotoryye rezul'taty palinologicheskikh issledovaniy na arkhipelage
Severnaya Zemlya $v$ svyazi $s$ voprosom o perenose pyl'tsy i spor v vysokoshirotnoy Arktike [Some results of palynological studies on Severnaya Zemlya in connection with pollen and spore transfer in the high latitude Arctic]. Izvestiya Vsesoyuznogo Geograficheskogo Obshchestva 111(4): 330-334

Koerner R M 1966 Accumulation on the Devon Island ice cap, Northwest Territories, Canada. Journal of Glaciology 6(45): 383-392

Koerner R M 1979 Accumulation, ablation, and oxygen isotope variations on the Queen Elizabeth Islands ice caps, Canada. Journal of Glaciology 22(86): 25-41

Koerner R M, Fisher D A 1982 Acid snow in the Canadian high Arctic. Nature 295(5845): 137-140

Lichti-Federovich S 1974 Pollen analysis of surface snow from the Devon Island ice cap. Geological Survey of Canada. Paper 74-1, Part A: 197-199

Lichti-Federovich S 1975[a] Pollen analysis of ice core samples from the Devon Island ice cap. Geological Survey of Canada. Paper 75-1, Part A: 441-444

Lichti-Federovich S 1975[b] Pollen analysis of surface snow from five Canadian Arctic ice caps. Geological Survey of Canada. Paper 75-1, Part B: 135-137

McAndrews J H 1984 Pollen analysis of the 1973 ice core from Devon Island ice cap, Canada. Quaternary Research 22(1): 68-76

Maxwell J B 1980 The climate of the Canadian Arctic islands and adjacent waters. Vol. 1. Ottawa, Environment Canada, Atmospheric Environment Service (Climatological Studies 30)

Orvig S (ed) 1970 Climates of the polar regions. Amsterdam etc, Elsevier

Rahn K A, McCaffrey R J 1980 On the origin and transport of the winter Arctic aerosol. Annals of the New York Academy of Sciences 338: 486-503

Ritchie J C, Lichti-Federovich S 1967 Pollen dispersal phenomena in Arctic and sub-Arctic Canada. Review of Palaeobotany and Palynology 3: 255-266

Schmidt F H 1973 Some aspects of the transport process in the atmosphere. In Nilsson $\mathrm{S}$ (ed) Scandinavian aerobiology symposium, Sweden, April 1972. Stockholm, Statens Naturvetenskapliga Forskningsråd. Ecological Research Committee: 53-59 (Ecological Research Committee. Bulletin 18) 